\title{
Peran Lembaga Alternatif Penyelesaian Sengketa Perbankan Indonesia (LAPSPI) dalam Penyelesaian Sengketa Pembiayaan di Bank Syariah
}

\author{
Tengku Rahmah Ramadhani ${ }^{1}$, Andri Brawijaya ${ }^{2}$, Imam Abdul Aziz ${ }^{3}$ \\ Universitas Djuanda ${ }^{1}$, Universitas Djuanda ${ }^{2}$, Universitas Djuanda ${ }^{3}$ \\ tengkurahma328@gmail.com ${ }^{\mathbf{1}}$, imamabdulaziz08@gmail.com², \\ andry.brawijaya@unida.ac.id ${ }^{3}$
}

\begin{abstract}
The purpose of this study was to determine the Role of the Indonesian Banking Dispute Resolution Alternative Institution (LAPSPI) in Financing Dispute Resolution at Islamic Banks and the dispute settlement process at LAPSPI. The method used is a qualitative descriptive method using content analysis. The data sources used are primary data and secondary data. Based on the results of research related to the role of the Indonesian Banking Dispute Resolution Alternative Institution (LAPSPI), it cannot be used as the main choice in assisting the settlement of problematic financing disputes because it does not have executive power and the decision is a peace agreement. The settlement process at LAPSPI is divided into 3 (three), namely mediation, adjudication and arbitration.

Keywords: Alternative Dispute Resolution, Islamic Bank, LAPSPI
\end{abstract}

\begin{abstract}
Abstrak
Tujuan penelitian ini untuk mengetahui Peran Lembaga Alternatif Penyelesaian Sengketa Perbankan Indonesia (LAPSPI) dalam Penyeleseian Sengketa pembiayaan di Bank Syariah serta proses penyelesaian sengketa pada LAPSPI. Metode yang digunakan adalah metode deskriptif kualitatif dengan menggunakan content analysis. Sumber data yang digunakan berupa data primer dan data sekunder. Berdasarkan hasil penelitian terkait Peran Lembaga Alternatif Penyelesaian Sengketa Perbankan Indonesia (LAPSPI) belum dapat dijadikan pilihan utama dalam membantu penyelesaian sengketa pembiayaan bermasalah karena belum memiliki kekuatan eksekutorial dan putusan bersifat perjanjian perdamaian. Proses penyelesaian pada LAPSPI terbagi menjadi 3 (tiga) yaitu mediasi, adjudikasi dan arbitrase.
\end{abstract}

Kata Kunci: Alternatif Penyelesaian Sengketa, Bank Syariah, LAPSPI.

\section{PENDAHULUAN}

Meningkatnya perkembangan bisnis syariah di Indonesia berdampak bagi perekonomian Indonesia. Kehadiran bank pada setiap negara khususnya di Indonesia difungsikan untuk kesejahteraan masyarakat, perindustrian makro maupun mikro dimana pada masingmasing bidang terdapat peran tersendiri dan memiliki pengaruh terhadap perkembangan perekonomian negara secara signifikan (Fitria, 2015:76).

Bank Syariah sebagai salah satu sistem perbankan yang berlandaskan aturan Islam. Pada umumnya merupakan sebuah lembaga intermediator antara surplus unit dan deficit unit dengan melakukan 
Peran Lembaga Alternatif Penyelesaian Sengketa Perbankan Indonesia (LAPSPI) dalam Penyelesaian Sengketa Pembiayaan di Bank Syariah

kegiatan transaksi seperti penghimpunan dana dan penyaluran dana pada masyarakat dalam bentuk jasa-jasa pembiayaan perbankan lainnya (Setiyaningsih, Haryanti, \& Hana, 2020). Aturan tersebut sudah terdapat dalam Undang-undangg Nomor 10 Tahun 1998 tentang perubahan Undang-undang Nomor 7 Tahun 1992 tentang perbankan.

Sebagai salah satu strategi pengembangan bisnis, bank syariah meningkatkan kualitas produknya dengan mengeluarkan berbagai inovasi produk pembiayaan yang beragam dengan tujuan untuk membantu dan mensejahterakan masyarakat (Riftiani, Lestari, \& Hana, 2020). Dalam perkembangannya, bisnis tidak selalu berjalan baik sesuai rencana dengan tujuan mendapatkan keuntungan yang lebih dapat pula terjadi hal yang tidak terduga atau mendapatkan kerugian risiko yang biasanya terjadi pada bank, risiko yang terjadi disebabkan karena mudahnya proses pencairan dana kepada nasabah, pengecekan terhadap calon nasabah yang tidak teliti sehingga dapat menyebabkan dana akan mengendap yang berakibat pada operasional bank, dan menyebabkan nasabah tidak mampu melakukan pengembalian piutang kepada bank atau macet (gagal bayar) yang akhirnya berdampak terjadinya masalah atau sengketa (dispute) di antara pihak-pihak yang terlibat (Hidayati, 2015:170).

Permasalahan yang timbul dalam praktek perbankan syariah antara bank dengan nasabahh kemungkinan terjadi permasalahan seperti wanprestasi atau cidera janji yang disebabkan oleh salah satuu pihak komplain karena tidak sesuai antara realita dengan penawaran yang ditawarkan oleh bank (Absor, Hana, \& Nur, 2019), serta hak dan kewajiban yang tidak terpenuhi oleh salah satu pihak karena adanya cacat kontrak dalam sebuah akad perjanjian.

Pentingnya upaya perlindungan dan pemberdayaan nasabah adalah kewajiban suatu bank dalam memberikan perlindungan dan pengawasan hukum terhadap nasabah dengan pembagian hukum baik secara eksplisit maupun implisiit juga melalui bentuk perlindungan tidak langsung dengan menerapkan prinsip kehati-hatian dalam menyelesaikan berbagai keluhan dan pengaduan nasabah (Djohan, 2010:18). Terkait dengan penyelesaian sengketa perbankan syariah yang semula berada di Bank Indonesia (BI) kini berlaih ke OJK berdasarkan UU No. 21 tahun 2011 tentang Otoritas Jasa Keuangan (OJK) sehingga OJK sebagai Lembaga Jasa Keuangan memiliki fungsi dalam pengeawasan industri jasa keuangan serta melindungi kepentingan masyarakat baik dari segi pengaduan atau keluhan terhadap perbankan. Dalam hal penyelesaian suatu permasalahan antara bank dengan nasabah, OJK mengeluarkan aturan Nomor 1/POJK.07/2014 Tentang Lembaga Alternatif Penyelsaian Sengketa (LAPS) aturan ini mengatur mekanisme penyelesaian sengketa antar jasa lenbaga keuangan termasuk bank dengan nasabah baik secara internal maupun eksternal. 
Penyelesaian sengketa dalam dunia perbankan dapat diselesaikan melalui dua jalur penyelesaian yaitu jalur litigasi (pengadilan) dan jalur diluar pengadilan (non litigasi). Penyelesaian sengketa diluar jalur pengadilan yaitu Badan Arbitrase Syariah Nasional (BASYARNAS), Badan Arbitrase Nasional Indonesia (BANI), Badan Penyelesaian Sengketa Konsumen (BPSK), Badan Mediasi Indonesia (BMI) dan masih banyak lagi lembaga alternatif lain yang tiap-tiap lembaga memiliki kelebihan dan kekurangan masing-masing. Namun, sejak OJK memberikan amanah kepada beberapa asosiasi perbankan untuk membentuk lembaga khusus menyelesaikan suatu sengketa yang dikenal dengan Lembaga Alternatif Penyelesaian Sengketa Perbankan Indonesia (LAPSPI) untuk melindungi kepentingan konsumen dan masyarakat. Pendirian LAPSPI diharapkan mampu menuntaskan sengketa secara cepat, murah, adill dan efisien. Adanya LAPSPI diharapkan dapat membantu dan mendorong terus industri jasa keuangan pada bidang Perbankan juga memitigasi risiko hukum agar reputasi perbankan tidak menurun sehingga kepercayaan nasabah semakin meningkat dan memiliki loyalitas yang tinggi terhadap perbankan.

Dalam menangani kasus permasalahan sengketa yang ada di masyarakat, LAPSPI mempunyai beberapa alternatif penyelesaian agar permasalahan sengketa dapat diselesaikan dengan cepat dan lancar. Sehingga dengan adanya LAPSPI dapat menjadi solusi terbaik bagi perbankan khususnya bank syariah dalam menyelesaikan sengketa diluar jalur peradilan sesuai prosedur yang sudah tercantum dalam Undangundang di OJK. Sesuai dengan latar belakang di atas, terkait dengan latar belakang diatas maka dirumuskan beberapa pertanyaan yakni, Bagaimana peran LAPSPI dalam menyelesaian permasalahan sengketa pada Bank Syariah dan bagaimana proses penyelesaian sengketa yang terdapat di LAPSPI.

\section{KAJIAN LITERATUR}

\section{Penyelesaian Sengketa Pembiayaan}

Penyelesaian pembiayaan yang terjadi antara nasabah dengan bank apabila telah dilakukan proses restrukturisasi tidak memenuhi kewajiban pembayaran, maka bank akan memberikan bantuan alternatif lain dengan melibatkan pihak eksternal yaitu lembaga professional yang ahli untuk menyelesaikan pembiayan bermasalah. Apabila melalui bantuan lembaga tidak menemukan kesepakatan dan nasabah sudah tidak memiliki itikad baik kepada bank dalam penyelesaian kewajibannya maka penyelesaian pembiayaan diselesaikan melalui pengadilan dengan cara menggugat atau gugatan, eksekusi akta pengakuan hutang, somasi, eksekusi sertifikat hak tanggungan dan eksekusi jaminan (Mardiana, 2017:420). 
Peran Lembaga Alternatif Penyelesaian Sengketa Perbankan Indonesia (LAPSPI) dalam Penyelesaian Sengketa Pembiayaan di Bank Syariah

Peran lembaga penyelesaian diharapkan dapat membantu dalam penyelesaian pembiayaan macet (bermasalah) antara nasabah dengan bank. Proses penyelesaian dibagi menjadi dua yakni litigasi (pengadilan) dan non litigasi (luar pengadilan). Di Indonesia terdapat badan penyelesaian sengketa yang sudah terbentuk mulai dari Badan Penyelesaian Sengketa Konsumenn (BPSK), Badan Arbitase Syariah Nasional (BASYARNAS), Badsn Arbitrase Nasional Indonesia (BANI) dan Lembaga yang diinisiasi pendirian nya oleh OJK yaitu Lembaga Alternatif Penyelesaian Sengketa Perbankan Indonesia ( LAPSPI ).

\section{Badan Penyelesaian Sengketa Konsumen (BPSK)}

Keberadaan Badan ini diatur dalam Undang-undang Penyelesaian Konsumen nomor. 8 Tahun 1999 Bab XI Pasal 49 sampai Pasal 58. Pada Pasal 49 ayat 1 dinyatakan bahwa pemerintah melakukan pembentukan badan alternatif penyelesaian sengketa konsumen pada Daerah Tingkat II sebagai akternatif penyelesaian sengketa konsumen di luar area pengadilan. Putusan lembaga BPSK tidak sesuai kompetensi dalam pengambilan putusannya terlalu memihak pada konsumen, anggota dari BPSK tidak ada yang berasal dari ruang lingkup perbankan, kurangnya pengawasan terhadap lembaga tersebut dan kurangnya informasi sehingga masyarakat sulit untuk mengakses lembaga tersebut. Akan tetapi disisi lain BPSK terus memperbaiki tata kelola nya agar menjadi lebih baik.

2. Badan Arbitrase Syariah Nasional (BASYARNAS)

berdiri tahun 2003 hingga sekarang, kewenangan Badan Arbitrase Syari'ah Nasional (BASYARNAS) sebagai lembaga pemutus, pemeriksa dan menyelesaikan perkara dibidang ekonomi syariah. Bersamaan dengan berdirinya BMI pada tahun 1993, BASYARNAS yang sebelumnya bernama Badan Muamalat Indonesia (BAMUI) diusulkan pendiriannya oleh Majelis Ulama Indonesia (MUI). Proses penyelesaian pada Basyarnas lebih mengedepankan pada sisi perdamaian antara para pihak.

3. Badam Arbitrase Nasional Indonesia (BANI)

Badan Arbitrse Nasional Indonesia (BANI) terdengar tidak terlalu umum dan kurang menjadi pilihan penyelesaian senketa di kalangan konsumen, karena menyangkut akomodasi yang harus dikeluarkan konsumen tidak sebanding dengan nilai sengketa konsumen dengan pelaku usaha. Proses penyelesaian sengketa tidak selalu mendapatkan hasil akhir yang memuaskan para pihak yang bersengketa.

4. Lembaga Alternatif Penyelesaian Sengketa Perbankan Indonesia (LAPSPI)

Lembaga yang pembentukannya di inisiasi oleh OJK bersama anggota asosiasi perbankan yang merupakan forum alternative penyelesaian sengketa di luar pengadilan yang adil dan tidak terikat oleh pihak lain. Forum penyelesaian lebih memfokuskan pada itikad baik dan menciptakan 
kelestarian hubungan jangka panjang para pihak sehingga tidak terciptanya permusuhan apabila suatu permasalahan telah diselesaikan.

Dari beberapa lembaga alternative penyelesaian sengketa yang telah dijelaskan terdapat kekurangan dan kelebihan masing-masing diantaranya memiliki biaya yang murah, informasi yang terdapat pada lembaga tersebut bersifat tertutup sehingga menjaga kerhasiaannya, proses penyelesaian yang cepat dan adil serta putusan yang bersifat perdamaian antara para pihak yang dibuktikan dengan melakukan perjanjian diatas kertas, tetapi apabila dari lembaga tersebut ingin memiliki putusan eksekutorial yang kuat apabila terdapat nasabah macet yang sudah sulit ditemui oleh petugas bank dan tidak diketahui keberadaannya makan dapat menggunakan jalur pengadilan untuk memiliki kekuatan eksekutorial sehingga dapat melakukan eksekusi jaminan nasabah tetapi untuk penyelesaian kasus di pengadilan membutuhkan waktu yang cukup lama dalam penyelesaiannya dan biaya yang tidak sedikit karena system penyelesaian di pengadilan berjenjang sehingga apabila terdapat pihak yang tidak puas akan putusan dipengadilan maka pihak tersebut dapat mengajukan gugatan banding pada pengadilan yang nantinya memakan waktu, tenaga dan biaya.

\section{Lembaga Alternatif Penyelesaian Sengketa Perbankan Indonesia (LAPSPI)}

Pembentukan Lembaga didasarkan kepada peraturan Otoritas Jasa Keuangan (POJK) Nomor 1/POJK.07/2014 Tentang lembaga alternatif penyelesaian sengketa di sektor jasa keuangan dengan diteruskan melalui MoU antara 6 (enam) Asosiasi Perbankan yakni Perhimpunan Bank Nasional (PERBANAS), Himpunan Bank Miliki Negara (HIMBARA), Asosiasi Bank Pembangunan Daerah (ASBANDA), Asosiasi Bank Syariah Indonesia (ASBISINDO), Pehimpunan Bank-Bank Internasional Indonesia (PERBINA), dan Perhimpunan Bank Perkreditan Rakyat Indonesia (PERBARINDO) tanggal 5 Mei 2014.

Pendirian LAPSPI tidak terlepas dari penyelesaian sengketa konsumen yang terkadang tidak mencapai kesepakatan antara konsumen dengan lembaga keuangan (Bank) sehingga LAPSPI dibentuk dan ditangani oleh orang-orang yang memahami dunia perbankan dan mampu menyelesaiakan proses sengketa secara cepat, murah dan adil dan efisien.

Setelah pendirian LAPSPI terdaftar pada OJK tahun 2015 kemudian LAPSPI mulai beroperasi pada awal Januari 2016. Anggaran dasar LAPSPI dituangkan dalam akta no. 36 tanggal 28 April 2015 oleh Notaris Ashoya Ratam., S.H., Mkn dan sudah mendapatlan persetujuan dari Menkumhan berdasarkan surat keputusan nomor AHU-0004902.AH.01.07 Tahun 2015 tanggal 16 September 2015. 
Peran Lembaga Alternatif Penyelesaian Sengketa Perbankan Indonesia (LAPSPI) dalam Penyelesaian Sengketa Pembiayaan di Bank Syariah

Strategi pengembangan LAPSPI didasarkan kepada Strategi Nasional Perlindungan Konsumen dan Rencana Pengembangan Jangka Menengah Nasional Undang-undang Nomor 8 Tahun 1999 tentang perlindunagn konsumen, Peraturan Otoritas Jasa Keuangan (POJK) Nomor 1/POJK.07/2013 Tentang Perlindungan Konsumen Sektor Jasa Keuangan.

\section{Visi LAPSPI}

Menjadi lembaga alternatif penyelesaian sengketa yang professional, adil, terpercaya dan pilihan utama nasabah dan bank dalam menyelesaikan sengketa.

\section{Misi LAPSPI}

a. memberikan pelayanan alternatif penyelesaian sengketa yang adil, murah, cepat dan efisien.

b. menyediakan skema layanan penyelesaian sengketa yang mudah diakses oleh konsumen.

c. menyediakan tenaga Mediator, Adjudikator dan Arbiter yang kompeten, kredibel dan memiliki integritas.

d. melaksanakan tata kelola lembaga berjalan dengan baik sesuai dengan prinsip transparansi, akuntabilitas, responsibilitas, indepedensi, dan kewajaran (fairness)

e. mendorong industry perbankan dan masyarakat menggunakan LAPSPI sebagai lembaga alternatif penyelesaian sengketa yang utama.

\section{Struktur LAPSPI}

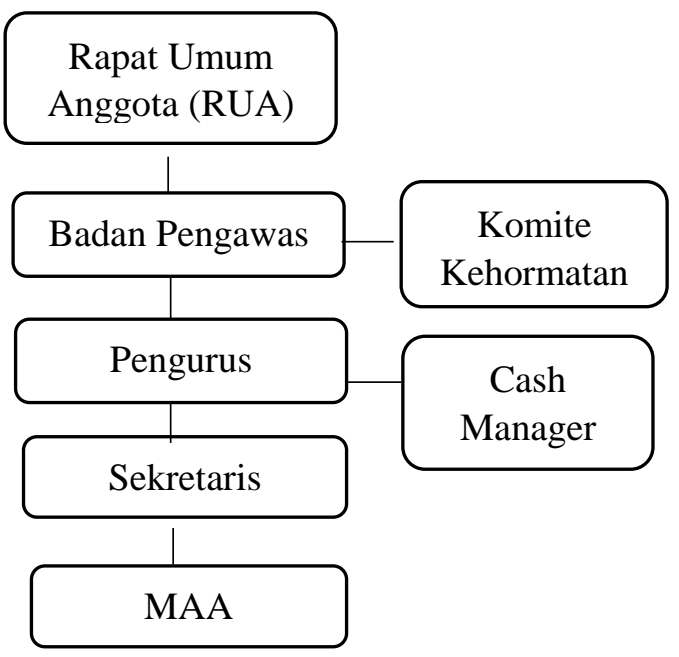

Gambar 1. Struktur Organisasi LAPSPI

Sumber : LAPSPI 
Organisasi LAPSPI terdiri dari :

a. Rapat Umum Anggota

b. Badan Pengawas

c. Pengurus

d. Sekretaris

e. Mediator, Adjudikator dan Arbitrase (MAA)

f. Komite Kehormatan

Pengurus, Badan Pengawas dan Dewan Kehormatan

a. Pengurus

Pada LAPSPI pengurus diangkat melalui Rapat Umum Angngota (RUA) dari beberapa calon yang telah diusulkan oleh anggota dari asosiasi perbankan sesuai dengan kesepakatan. Masa jabatan pengurus adalah 4 tahn dan dapat ditunujuk kembali. Pengurus terdri dari ketua, sekertaris dan bendahara.

Pengurus LAPSPI dalam periode pendirian sebagai berikut :

1) Ketua : : Hilmawan E Subiantoro

2) Sekretaris : Andi Akhmad Sutardi

3) Bendahara : Nirwana Atta

b. Badan Pengawas

Di dalam badan pengawas LAPSPI terdiri dari ketua atau wakil ketua, anggota dan dalam sebuah badan pengawas mempunyai anggota yang sama dengan jumlah asosiasi pada sektor Perbankan. Badan pengawas diangkat dan dipilih oleh Rapat Umum Anggota (RUA), masa jabatan badan pengawas terhitung sejak pengangkatan dan pemilihan oleh RUA dan dapat dipilah maksimul 1 (satu) masa jabatan berikutnya.

c. Dewan Kehormatan

Dewan kehormatan diangkat oleh pengurus dengan mendapat persetujuan dari Badan Pengawas untuk masa jabatan 3 tahun. Tugas utama nya adalah menyelesaikan seluruh persoalan yang menyangkut pelanggaran pada Kode Etik yang dilakukan oleh Mediator, Adjudikator dan Arbiter LAPSPI. Logo LAPSPI

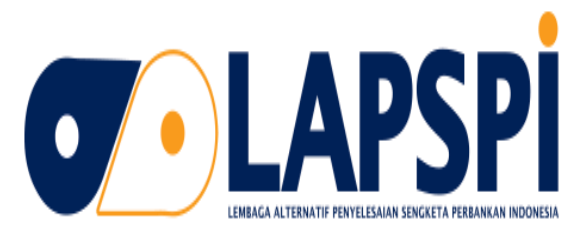

\section{Gambar 2. Logo LAPSPI \\ Sumber : LAPSPI}

Gambar logo berupa anak mata rantai sepeda yang saling berkaitan yang berarti bahwa antara pihak Bank dan Nasabah adalah pihak yang saling terkait dan memiliki tujuan bersama. Kedua rantai sepeda memiliki 
Peran Lembaga Alternatif Penyelesaian Sengketa Perbankan Indonesia (LAPSPI) dalam Penyelesaian Sengketa Pembiayaan di Bank Syariah

kepentingan berbeda yang digambarkan dengan bentuk yang saling terbalik dan warna yang berbeda. Warna biru menggambarkan kepercayaan, keseriusan, keyakinan dan profesional. Warna kuning menggambarkan suasana kebahagiaan, optimisme dan persahabatan. Berpaduan kedua warna menggambarkan suasana para pihak yang berlandaskan kepercayaan dan keyakinan dalam sebuah permasalahan.

\section{Penyelesaian Sengketa menurut Islam}

Islam telah memberikan wadah yang sempurna dalam menyelesaikan sengketa yang terjadi antara manusia dalam berbagai sisi kehidupan. Hal tersebut di klasifikasikan dalam dua kelompok yaitu penyelesaian sengketa yang dilakukan oleh kehakiman dan yang dilakukan diluar badan kehakiman.

Kekuasaan kehakiman dalam Islam diurai lagi menjadi tiga bagian, pertama kekuasaan Al-Qadla, yaitu lembaga yang berwenang untuk menyelesaikan perkaraperkara perdata dan pidana. Kedua, kekuasaan AlHisbah, yakni lembaga resmi pemerintah yang diberi kewenangan untuk menyelesaikan pelanggaran-pelanggaran ringan yang menurut sifatnya tidak memerlukan proses peradilan, seperti pengurangan takaran timbangan, kendaraan yang melebihi kapasitas angkut, dan lainnya. Dan ketiga, kekuasaan Al-Madzalim, yaitu lembaga yang dibentuk untuk membela dan menyelesaikan perkara akibat kesewenangan penguasa, pejabat, hakim, atau lainnya.

Sementara penyelesaian perkara diluar kekuasaan kehakiman dapat dilakukan melalui as-sulhu (perdamaian) atau at-tahkim (arbitrase).

Adapun ayat Al-Quran yang menerangkan mengenai penyelesain sengketa:

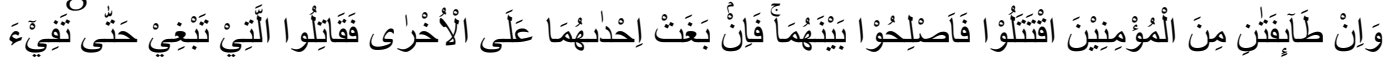

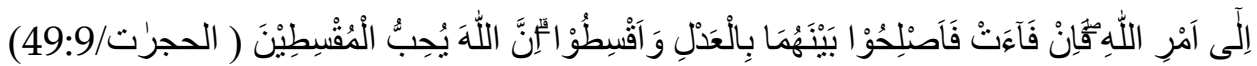

Artinya : "Dan kalau ada dua golongan dari mereka yang beriman itu berperang hendaklah kamu damaikan antara keduanya! tapi kalau yang satu melanggar Perjanjian terhadap yang lain, hendaklah yang melanggar Perjanjian itu kamu perangi sampai surut kembali pada perintah Allah. kalau Dia telah surut, damaikanlah antara keduanya menurut keadilan, dan hendaklah kamu Berlaku adil; Sesungguhnya Allah mencintai orangorang yang Berlaku adil" Q.S Al-Hujurat ayat 9.

\section{Bank Syariah}

Perbankan syariah yaitu segala sesuatu yang terikat oleh bank syariah, unit usaha syariah, mencakup kelembagaan, kegiatan usaha, serta proses pelaksanaannya sesuai dengan jenis usahanya. Bank syariah adalah 
bank yang menjalankan kegiatan usahanya sesuai dengan prinsip syariah. Di Indonesia lembaga perbankan syariah didirikan pada tahun 1992 hingga kini perkembangan sudah semakin pesat bahkan berjumlah 199 unit bank syariah. Sesuai dengan nama lembaganya Bank Syariah yakni produk yang dikeluarkan berbasis syariah dan pembagaian keuntungan ditetapkan berdasarkan margin yang disepakati pada awal akad.

\section{Fungsi Bank Syariah}

Lembaga keuangan syariah memiliki 3 fungsi yaitu menyimpan dana masyarakat dalam bentuk simpanan atau investasi, menyalurkan dana kepada masyarakat dalam bentuk pembiayaan, dan memberikan jasa pelayanan yang sangat baik dalam bentuk jasa perekonomian syariah.

\section{Tujuan Bank Syariah}

Tujuan Bank Syariah selain mengubah prinsip bunga dengan prinsip bagi hasil untuk tujuan kemaslahatan masyarakat.

\section{METODE PENELITIAN}

Jenis penelitian yang dilakukan adalah penelitian deskriptif kualitatif. Pendekatan kualitatif dilakukan untuk menunjukan suatu pembahasan secara jelas mengenai tulisan yang sedang dibahas. Penelitian kualitatif menggunakan metode content analysis yaitu menganalisis isi dan membandingkan berbagai simbol dalam media atau teks dengan mengkaji dokumen-dokumen berupa kategori umum dari makna. Kemudian memberi gambaran tentang peran sebuah lembaga alternatif penyelesaian sengketa pada perbankan serta proses penyelesaiannya. Analisis isi akan mengkaji dengan menentukan objek penelitian yang akan menjadi objek sasaran analisis. Apabila objek yang sedang diteliti berhubungan dengan data verbal sehingga disebutkan tempat kejadian, tanggal dibuat dan bentuk komunikasi yang digunakan dalam penelitian. Objek penelitian dilakukan untuk mengidentifikasi terhadap fungsi penerapan yang mengantarkan objek tersebut.

Teknik dalam penelitian ini dilakukan dengan cara wawancara pihak terkait, observasi dan dokumentasi lapangan terhadap apa yang telah dilakukan. Sedangkan umber data yang digunakan terdiri atas data primer dan data sekunder, data primer yaitu data yang menjadi sumber dalam penelitian dilakukan dengan wawancara, studi kasus, observasi, dokumentasi dan lainnya. Sedangkan data sekunder yaitu data yang digunakan sebagai data penunjang dalam penelitian.

Metode analisis data dalam penelitian ini ialah menguraikan suatu bahan penelitian dengan menganalisis dan menelaah keseluruhan materi yang diambil dan dibuat kesimpulan untuk memberikan pemahaman. Data yang didapatkan akan di analisa dan diolah untuk menghasilkan jawaban 
Peran Lembaga Alternatif Penyelesaian Sengketa Perbankan Indonesia (LAPSPI) dalam Penyelesaian Sengketa Pembiayaan di Bank Syariah

dari rumusan permasalahan. Data yang didapat dari hasil interview dan observasi kemudian dikaitkan dengan sumber data sekunder untuk kemudian diambil kesimpulan mengenai Peran LAPSPI dalam proses penyelesaian sengketa pembiayaan di Bank Syariah.

\section{HASIL DAN PEMBAHASAN}

Pembahasan mengenai hasil penelitian yang dilakukan bermula dari proses penyelesaian sengketa pembiayaan bermasalah melalui jalur internal dispute resolution pada salah satu bank syariah yakni Bank BNI Syariah yang merupakan bagian anggota LAPSPI dari asosiasi ASBISINDO yang selalu membayar iuran setiap tahunnya berdasarkan buku yang telah ditetapkan oleh OJK yang kemudian dilanjutkan pada jalur External Dispute Resolution melalui Lembaga Alternatiif Penyelesaian Sengketa Perbankan Indonesia (LAPSPI) serta sudah sejauh mana peran LAPSPI dalam ruang lingkup perbankan khususnya bank syariah.

\section{Internal Dispute Resolution (IDR) pada Bank BNI Syariah}

Penyelesaian sengketa yang dilakukan secara internal pada lembaga keuangan khususnya perbankan. hal utama yang harus dilakukan ialah menyelesaikan suatu permasalahan dengan melakukan negosiasi dengan nasabah dan tetap dilakukan penagihan sesuai dengan kewajiban pembayaran yang telah ditentukan oleh bank. Pada dasarnya suatu permasalahn yang terjadi di lembaga keuangan tidak dapat dihindari dan akan selalu terjadi. Permasalahan yang terjsdi di lembaga keuangan sangatlah beragam dimulai dari permasalahan kartu kredit, pembiayaan dan permasalahan pelayanan bank kepada nasabah. Apabila proses negosiasi telah dilakukan selanjutnya akan dilakukan proses restrukturisasi pembiayaan yakni dengan memperkecil angsuran atau pembayaran dengan syarat perpanjangan waktu jatuh tempo, adapun cara lain dengan menawarkan menggunakan skema penjadwalan pembiayaan kembali.

Hal tersebut dilakukan apabila nasabah tersebut masih dapat ditemui dan diajak untuk melanjutkan hubungan yang baik. Tetapi, apabila nasabah sudah tidak dapat ditemui dan tidak diketahui keberadaan nasabah tersebut maka pihak Bank akan melakukan uoaya lain seperti melakukan penjualan agunan yang dilakukan secara sukarela dalam rangka menyelesaikan pembiayaan, agunan yang diambil alih (AYDA) yakni agunan nasabah yang diambil alih oleh bank tersebut akan dijual melalui pelelangan yang dilakukan oleh bank atau melalui kantor lelang, dan yang terakhir melalui jalur litigasi (pengadilan) menurut pihak bank penyelesaian masalah sengketa jauh lebih baik dibandingkan penyelesaian sengketa yang lainnya karena putusan yang diberikan oleh pengadilan 
sudah kuat dan sah dimata hukum sehingga pihak nasabah suka tidak suka wajib mengikuti aturan yang ditetapkan oleh pengadilan.

\section{External Dispute Resolution (EDR) pada Lembagaa Alternatif Penyelesaian Sengketa Perbankan Indonesia (LAPSPI)}

LAPSPI sudah menyelesaikan kurang lebih 99 kasus perkara sampai bulan April 2018 hal ini bukanlah angka yang besar, tetapi sesuai dengan kurun waktu berjalannya lembaga ini yang masih terbilang sangat muda. Banyak kasus mediasi yang mampu diselesaikan oleh Lembaga Alternatif Penyelesaian Sengketa Perbankan Indonesia (LAPSPI) sehingga telah sesuai dengan amanat POJK No.1 tahun 2014.

Mengenai proses hukum yang terdapat di LAPSPI, sejak awal menggunakan sistem berjenjang dalam setiap penyelesaian permasalahannya. Pada tahap mediasi penyelesaian hanya memiliki satu jenjang sesuai dengan Undang-undang Mediasi, sedangkan untuk tahap adjudikasi dan arbitrase jika ingin mempunyai keputusan yang kuat harus didaftarkan berdasarkan akta notaris kepada Pengadilan agar mendapat kekuatan eksekutorial.

Proses penyelesaian sengketa di LAPSPI tidak jauh berbeda dengan lembaga penyelesaian pada umumnya, hanya saja proses penyelesaian di LAPSPI lebih cepat, efisien, efektif, terjamin kerahasiaannya dan memiliki biaya terjangkai apabila dibandingkan dengan Pengadilan Agama. LAPSPI mengkategorikan segmen nasabah atau konsumen kedalam beberapa kategori, yaitu apabila terdapat nasabah atau konsumen yang ingin menyelesaikan sengketa dibawah RP. 500.000.000,- (lima ratus juta rupiah) atau bahkan mencapai Rp.1.000.000.000.000,- (satu triliun rupiah). Sesuai dengan peraturan yang diterapkan oleh OJK sangat jauh berbeda. Berdasarkan POJK No. 1 tahun 2013 tentang konsumen sektor jasa keuangan pasal 41 huruf (a) nasabah/konsumen yang mengalami kerugian maksimal Rp.500.000.000,- (lima ratus juta rupiah). Namun dalam hal ini kembali pada permintaan si nasabah karena karakteristik nasabah yang bermacam-macam.

Biaya penyelesaian perkara di LAPSPI terdapat 2 kategori, yaitu layanan Probono dan layanan Komersial. Layanan Probono (Cuma-Cuma) disebut pula layanan tak berbayar diperuntukan bagi nasabah kecil/perorangan dan perusahaan UMKM dimana tuntutan ganti ruginya sampai dengan Rp.500.000.000,- (lima ratus juta rupiah) disebut pula nasabah Basic Saving Account (BSA) adalah nasabah yang memiliki saldo kecil atau saldo minimal Rp.20.000.000,- (dua puluh juta rupiah) sesuai dengan POJK No.19 tahun 2014 pasal 5 angka (2) tentang layanan keuangan tanpa Kantor dalam Rangka Keuangan Inklusif, nasabah yang berperkara dan mengalami kerugian finansial kurang dari Rp.500.000.000,- (lima ratus juta) termasuk kategori layanan Probono dan dapat digratiskan dalam 
Peran Lembaga Alternatif Penyelesaian Sengketa Perbankan Indonesia (LAPSPI) dalam Penyelesaian Sengketa Pembiayaan di Bank Syariah

biaya penyelesaian sengketa di LAPSPI sehingga biaya tersebut ditanggung oleh OJK dan pihak LAPSPI. Sedangkan pada Layanan Komersial disebut pula layanan berbayar diperuntukan bagi nasabah diluar nasabah yang telah ditetapkan sebagai nasabah yang mendapatkan layanan probono.

Tabel 1 Skema Layanan

\begin{tabular}{|c|c|}
\hline \multicolumn{2}{|c|}{ Skema Layanan } \\
\hline $\begin{array}{l}\text { Probono (Tak } \\
\text { berbayar) } \\
<\text { Rp. } \\
500.000 .000 \\
\text { Kategori: } \\
\text { Nasabah Basic } \\
\text { Saving Account } \\
\text { (BSA), saldo } \\
\text { minimal Rp. } \\
20.000 .000\end{array}$ & $\begin{array}{l}\text { Proses berjenjang } \\
\text { melalui mediasi } \\
\text { dan adjudikasi } \\
\text { Biaya: } \\
\text { adjudikator, } \\
\text { pendaftaran Rp. } \\
2.000 .000 \\
\text { Jasa Adjudikator } \\
\text { Rp. } 10.000 .000\end{array}$ \\
\hline $\begin{array}{l}\text { Komersial } \\
\text { (Berbayar) } \\
\text { > Rp. } \\
500.000 .000\end{array}$ & $\begin{array}{l}\text { Biaya: Arbitrase, } \\
\text { pendaftaran Rp. } \\
20.000 .000 \\
\text { Jasa arbiter Rp. } \\
60.000 .000\end{array}$ \\
\hline
\end{tabular}

Sumber: Buku tahunan LAPSPI

Biaya perkara dengan kerugian finansial Rp.500.000.000 (lima ratus juta) maka akan langsung masuk pada proses mediasi dan adjudikasi. Pada proses Adjudikasi, nasabah atau konsumen akan dikenakan biaya dalam penyelesaian perkara. Biaya yang dikenakan pada proses pendaftaran sekitar Rp.2.000.000,- (dua juta rupiah) dan biaya jasa adjudikator sebesar Rp.10.000.000,- (sepuluh juta rupiah). Sedangkan pada proses arbitrase, apabila tuntutan perkara kerugian finansial diatas Rp.500.000.000 (lima ratus juta) maka akan langsung memasuki proses arbitrase, dengan biaya pendaftaran Rp. 20.000.000,- (dua puluh juta rupiah) dan biaya jasa arbiter sebesar Rp.60.000.000,-(enam puluh juta rupiah).

Dalam menyelesaikan suatu permasalahan sengketa baik di sebuah lembaga atau badan tidak selalu berjalan lancar, pada LAPSPI sendiri terdapat beberapa perkara yang dapat terselesaikan, pending sampai tahan ditolak. Adapun akumulasi periode 1 januari 2016 - 31 Desember 2018, LAPSPI telah menerima pengaduan/sengketa dari nasabah sebanyak 134 pengaduan/sengketa, dengan rincian sebagai berikut:

- Tahun 2016 sebanyak 27 sengketa 
- Tahun 2017 sebanyak 46 sengketa

- Tahun 2018 sebanyak 61 sengketa

Jenis pengaduan yang masuk terdiri dari Kredit, Kartu kredit, dan Ebanking.

Tabel 2 Pengaduan LAPSPI Periode 1 Januari 2016 - 31 Desember 2018

\begin{tabular}{|c|l|c|c|c|c|c|}
\hline No & \multicolumn{1}{|c|}{ Kasus } & Selesai & Pending & Ditolak & $\begin{array}{c}\text { Kembali pada } \\
\text { tahap IDR }\end{array}$ & Total \\
\hline 1 & Kredit & 11 & 3 & 18 & 28 & 60 \\
\hline 2 & Kartu Kredit & 15 & 1 & 5 & 30 & 51 \\
\hline 3 & Dana & 4 & 2 & 1 & 5 & 12 \\
\hline 4 & E-banking & 6 & 0 & 0 & 5 & 11 \\
\hline \multicolumn{2}{|c|}{ Total kasus } & 36 & 6 & 24 & 68 & 134 \\
\hline
\end{tabular}

Sumber: Laporan tahunan LAPSPI

Diantaranya pada kasus Kredit total 60, 11 terselesaikan, 3 dipending, 18 ditolak, 28 kembali pada tahap Internal Dispute Resolution (IDR), kemudian pada kasus Kartu kredit total 51, diantaranya 15 terselesaikan, 1 dipending, 5 ditolak, 30 kembali pada tahap Internal Dispute Resolution (IDR), pada kasus permasalahan lingkup dana total 12, diantaranya 4 terselesaikan, 2 dipending, 1 ditolak, 5 kembali pada tahap Internal Dispute Resolution (IDR), dan adapula pada kasus E-Banking/Internet Banking/Mobile Banking total kasus yaitu 11, diantaranya 6 terselesaikan, 5 dikembalikan pada tahap Internal Dispute Resolution (IDR).

Akumulasi Layanan LAPSPI Periode 1 Januari 2016 - 31 Desember 2018

- Diselesaikan melalui mediasi sebanyak 35 sengketa

- Diselesaikan melalui arbitrase sebanyak 1 sengketa

- Pending oleh LAPSPI sebanyak 6 sengketa

- Ditolak karena tidak memenuhi persyaratan sebanyak 6 sengketa

- Dikembalikan pada proses IDR sebanyak 68 sengketa

\section{Peran LAPSPI dalam Penyelesaian Sengketa Pembiayaan di Bank Syariah}

Pembiayaan bermasalah (macet) menurut data di OJK setiap tahunnya meningkat, terlebih jika dikaitkan dengan data yang terdapat pada salah satu bank yakni Bank BNI Syariah dimana mengalami peningkatan jumlah nasabah macet setiap tahunnya dan proses penyelesaian yang beragam. Tetapi, apabila dikaitkan dengan lembaga alternatif yang digunakan oleh Bank BNI Syariah pada kenyataannya bank tersebut tidak menggunakan LAPSPI sebagai lembaga allternatif penyelesaian. Menurut pihak bank LAPSPI hampir sama seperti lembaga dalam proses negosiasi dan restruktusirasi dengan pihak nasabah. Sedangkan permasalahan yang terjadi kadang nasabah sulit ditemui atau kabur sehinngga terkendala 
Peran Lembaga Alternatif Penyelesaian Sengketa Perbankan Indonesia (LAPSPI) dalam Penyelesaian Sengketa Pembiayaan di Bank Syariah

dalam proses penyelesaiannya, apabila pihak bank menggunakan LAPSPI maka hanya berfokus pada negosiasi saja tidak dapat menemukan titik temu dari permasalahan. Sehingga LAPSPI dianggap belum dapat dijadikan sebagai pilihan utama dalam proses penyelesaian.

Selain itu masih terdapat bank syariah yang belum mencantumkan LAPSPI dalam klausula baku akad perjanjian antara bank dengan nasabah sehingga tidak adanya kewajiban bagi lembaga jasa keuangan untuk menggunakan lembaga tersebut.

\section{Proses Penyelesaian melalui Mediasi, Adjudikasi dan Arbitrase}

\section{Proses penyelesaian melalui mediasi}

a. Proses mediasi diselenggarakan berdasarkan Permohonan Mediasi yang diajukan pendaftarannya oleh pemohon kepada LAPSPI. Berkas Permohonan Mediasi harus diisi terkait:

1) Nama lengkap, dan tempat tinggal atau tempat kedudukan Para Pihak

2) Jenis perkara

3) Permintaan kepada LAPSPI untuk diselenggarakan Mediasi

4) Resume Perkara

5) Fotokopi dokumen-dokumen atau bukti-bukti pendukung

b. Resume dibuat oleh para pihak yang bersengketa.

c. Selanjutnya pengurus akan menyampaikan surat pemberitahuan apakah permohonan tersebut mendapat penerimaan atau penolakan terhadap pendaftaran Permohonan Mediasi kepada Para Pihak dalam waktu paling lama 10 (sepuluh) hari terhitung setelah diterimanya konfirmasi tertulis dari Termohon.

d. Apabila Permohonan Mediasi ditolak, maka surat tersebut harus dibuat memuat alasan penolakan. Kemudian para Pihak dapat melakukan pengajuan kembali permohonan mediasi setelah memenuhi persyaratan sebagaimana diatur dalam Peraturan dan Prosedur mediasi.

e. Apabila Permohonan Mediasi diterima, maka surat tersebut berisi mengenai penunjukan mediator, rincian biaya yang harus dikeluarkan, dan memberitahukan nama sekertaris yang ditunjuk LAPSPI untuk mengurus perkara yang bersangkutan.

f. Selanjutnya LAPSPI akan melakukan proses mediasi dan terjadinya proses perundingan mediasi yang berlangsung paling lama 30 (tiga puluh) hari. Pada saat proses mediasi hanya dihadiri oleh pihak termohon, pihak pemohon, seorang mediator dan sekertaris kecuali para pihak mengehendaki untuk membawa saksi.

g. Setelah melakukan proses mediasi akan mencapai pada kesepakatan maka Para Pihak dengan dibantu oleh Mediator harus menuangkan kesepakatan tersebut dalam Kesepakatan Perdamaian yang 
ditandatangani oleh Para Pihak dan Mediator sebagai saksi

\section{Proses penyelesaian melalui Adjudikasi}

a. Adjudikasi diselenggarakan berdasarkan permohonan adjudikasi dengan mengisi surat permohonan adjudikasi.

1) Nama lengkap dan tempat tinggal atau tempat kedudukan Para Pihak.

2) Resume Perkara tentang sengketa.

3) Isi tuntutan dan Fotokopi Perjanjian Adjudikasi.

4) Akta bukti. Fotokopi/salinan dokumen bukti-bukti.

b. Selanjutnya pengurus akan menyampaikan konfirmasi penerimaan atau penolakan terhadap permohonan pendaftaran adjudikasi paling lama 10 hari. Apabila permohonan adjudikasi ditolak maka pemohon dapat mengajukan kembali dengan memenuhi persyaratan adjudikasi. Sedangkan apabila permohonan adjudikasi diterima maka pengurus akan memberitahukan adjudikator yang ditunjuk, nama sekertaris dan Salinan permohonan adjudikasi untuk termohon.

c. Pihak yang menyetujui selanjutnya akan membuat perjanjian adjudikasi yang dibuat dalam waktu paling lamaa 5 hari. Dan melakukan pemeriksaan adjudikasi dalam waktu 60 hari sejak ditentukan adjudikator. Jika dalam pemeriksaan adjudikator terdapat kendala pemeriksaan maka akan diperpanjang paling lama 30 hari.

d. Apabila selama pemeriksaan para pihak bersepakat untuk mengupayakan perdamaian. Kemudian para pihak akan kembali kepada adjudikator untuk melaporkan hasil upaya perdamaian tersebut

e. Jika berhasil mencapai perdamaian, kesepakatan tersebut harus memuat klausula pencabutan Permohonan Adjudikasi dan menyatakan perkara telah selesai. Berdasarkan hal tersebut, Pemohon menyatakan mencabut Permohonan Adjudikasi di hadapan Adjudikator dan untuk selanjutnya Adjudikasi dinyatakan telah selesai.

f. Namun apabila dalam proses pemeriksaan adjudikator tidak terdapat kesepakatan, maka para pihak akan melanjutkan ke arbitrase atau pengadilan

\section{Proses Penyelesaian melalui Arbitrase}

Layanan Arbitrase dalam Peraturan dan Prosedur Undang-undang arbitrase ini diberikan untuk sengketa kerugian finansial di atas Rp.500.000.000,- (lima ratus juta rupiah). Untuk prosesnya sebagai berikut:

a. Para pihak melakukan pendaftaran permohonan arbitrase yang 
Peran Lembaga Alternatif Penyelesaian Sengketa Perbankan Indonesia (LAPSPI) dalam Penyelesaian Sengketa Pembiayaan di Bank Syariah

memuat

1) Nama lengkap dan tempat tinggal atau tempat kedudukan Para Pihak.

2) Uraian singkat tentang sengketa.

3) Isi tuntutan yang jelas dan lampiran-lampiran berisi bukti pembayaran, fotokopi perjanjian arbitrase, dan dokumen bukti lainnya.

b. Selanjutnya pengurus akan menyampaikan konfirmasi penerimaan atau penolakan terhadap permohonan pendaftaran arbitrase paling lama 10 hari. Apabila permohonan arbitrase ditolak maka pemohon dapat mengajukan kembali dengan memenuhi persyaratan. Sedangkan apabila permohonan adjudikasi diterima maka akan diberitahukan mengenai penunjukan arbiter, nama sekertaris dan Salinan permohonan arbiter untuk termohon.

c. Termohon harus memberikan tanggapan kepada Pemohon, dengan tembusan Pengurus, paling lama dalam waktu 10 (sepuluh) hari terhitung setelah menerima Salinan permohonan tersebut.

d. Setelah menentukan seorang arbiter yang dipilih oleh para pihak, selanjutnya dokumen tersebut akan diperiksa oleh arbiter.

e. Pemeriksaan arbitrase dilakukan paling lama 180 (seratus delapan puluh) hari terhitung sejak tanggal pengangkatan Arbiter.

f. Setelah terjadi pemeriksaan yang dilakukan oleh arbiter, selanjutnya akan dibacakan mengenai putusan arbitrase LAPSPI.

g. Masing-masing Pihak yang bersengketa dapat diwakili oleh kuasa hukumnya dengan surat kuasa yang bersifat khusus.

h. Selanjutnya akan diadakan panggilan sidang yang diajukan untuk termohon dan pemohon.

i. Apabila dalam proses persidangan terjadi sebuah kesepakatan perdamaian, maka Kesepakatan Perdamaian tersebut dituangkan ke dalam Keputusan Arbitrase yang bersifat final dan mengikat.

\section{KESIMPULAN}

Berdasarkan akar permasalahan dan pembahasan dari suatu penelitian tersebut sehingga dapat ditarik kesimpulan sebagai berikut:

1. Peran LAPSPI sebagai media alternatif penyelesaian sengketa pada bidang perbankan dianggap masih belum efektif dimana dalam menyelesaikan sengketa LAPSPI hanya mampu menyelesaikan 40 perkara setiap tahun dan 4 perkara tiap bulannya sehingga data tersebut kurang seimbang dibanding dengan data salah satu bank syariah yakni bank BNI Syariah dimana bank tersebut tidak menggunakan LAPSPI dalam penyelesaian permasalahan sengketanya dikarenakan LAPSPI tidak dapat memberikan kepastian hukum akan hak yang dimiliki bank sehingga keputusan di LAPSPI hanya bersifat 
perjanjian perdamaian kedua belah pihak bukan untuk mengekesekusi jaminan.

2. Mekanisme penyelesaian sengketa di LAPSPI terdapat 3 cara penyelesaian yaitu mediasi, adjudikasi dan arbitrase. Proses penyelesaian mediasi dibantu oleh seorang mediator yang nantinya akan membantu kedua belah pihak untuk menemukan jalan keluar dari suatu permasalahan, seorang mediator hanya untuk membantu bukan untuk mengambil keputusan. Tujuan dari bermediasi untuk mempertahankan hubungan jangka panjang dan penyelesaian dilakukan dengan tidak merugikan satu sama lain (win-win solution) sehingga hasil dari kesepakatan perdamaian yang bersifat mengikat dan final. Proses Adjudikasi dibantu oleh adjudikator yang ditunjuk untuk memeriksa perkara dan memberi putusan adjudikasi hasil dari putusan adjudikasi nantinya akan ditujukan kepada termohon untuk mengikuti kewajiban yang diajukan oleh pemohon, sehingga pada proses adjudikasi dianggap tidak fair. Untuk di LAPSPI sendiri belum melakukan penyelesaian adjudikasi karena terlalu mengikat pihak termohon (bank). Sedangkan proses arbitrase terdapat seorang arbiter yang dapat memutuskan suatu perkara, putusan arbitrase bersifat final dan mengikat dan dituangkan dalam surat perjanjian kesepakatan dengan disaksikan oleh para pihak.

Berdasarkan hasil penelitian yang dilakukan maka saran dari peneliti diantaranya:

1. Lembaga jasa keuangan mencantumkan Lembaga Alternatif Penyelesaian Sengketa Perbankan Indonesia (LAPSPI) dalam klausula baku perjanjian akad sebagai alternatif penyelesaian sengketa bila terdapat masalah sengketa dengan nasabah.

2. Lembaga Alternatif Penyelesaian Sengketa Perbankan Indonesia (LAPSPI) harus melakukan sosialisasi, atau membuat strategi pemasaran yang menarik untuk memperkenalkan lembaga kepada masyarakat.

3. Pihak lembaga Lembaga Alternatif Penyelesaian Sengketa Perbankan Indonesia (LAPSPI) melakukan perektutan SDM yang memahami persoalan di bidang perbankan syariah.

4. Untuk penelitian selanjutnya diharapkan untuk lebih mengkaji mengenai implementasi Lembaga Alternatif Penyelesaian Sengketa Perbankan Indonesia (LAPSPI) dalam menyelesaikan permasalahan sengketa di bidang perbankan, apakah ketentuan mengenai klausula baku sudah diterapkan oleh Lembaga Jasa Keuangan (LJK).

5. Diharapkan bagi pemerintah tidak terlalu banyak membentuk lembaga atau badan terkait penyelesaian sengketa, jika nantinya putusan yang dikeluarkan tidak memiliki kekuatan eksekutorial, dan sistem kerja yang tidak pasti. 
Peran Lembaga Alternatif Penyelesaian Sengketa Perbankan Indonesia (LAPSPI) dalam Penyelesaian Sengketa Pembiayaan di Bank Syariah

\section{DAFTAR PUSTAKA}

Absor, C., Hana, K. F., \& Nur, F. R. (2019). Ada Apa dengan Dewan Pengawas Syariah di Koperasi Simpan Pinjam dan Pembiayaan Syariah? MALIA: Journal of Islamic Banking and Finance, 3(2), 155-173.

Riftiani, R. I., Lestari, D. P., \& Hana, K. F. (2020). Implementation of Sharia Management in Islamic Mutual Fund Products Rizki Ikha Riftiani. Journal of Finance and Islamic Banking, 3(1), 77-94. https:/ / doi.org/10.22515/jfib.v3i1.2626

Setiyaningsih, A., Haryanti, I., \& Hana, K. F. (2020). Ada Apa Dengan Kinerja di Bank Panin Dubai Syariah? BanKu: Jurnal Perbankan Dan Keuangan, 1(Agustus), 60-74.

Ismail. (2013). Perbankan Syariah. Jakarta: Kencana Prenada Medua Group. Khodijah, Siti. (2018). Respon Praktisi Pada Penyelesaian Sengketa Perbankan Syariah Melalui Lembaga Alternatif Penyelesaian Sengketa Perbankan Indonesia (LAPSPI). Jakarta: Universitas Islam Negeri Syarif Hidayatullah.

Marimin, Agus. Dkk. (2015). Perkembangan Bank Syariah di Indonesia. Jurnal Ilmiah Ekonomi Islam, Vol 1 (2).

OE, Meita Djohan. (2010). Penyelesaian Sengketa antara Bank dan Nasabah oleh Lembaga Mediasi Perbankan. Jurnal Keadilan Progresif, Vol 1 (1).

Riftiani, R. I., Lestari, D. P., \& Hana, K. F. (2020). Implementation of Sharia Management in Islamic Mutual Fund Products Rizki Ikha Riftiani. Journal of Finance and Islamic Banking, 3(1), 77-94. https://doi.org/10.22515/jfib.v3i1.2626

Setiyaningsih, A., Haryanti, I., \& Hana, K. F. (2020). Ada Apa Dengan Kinerja di Bank Panin Dubai Syariah? BanKu: Jurnal Perbankan Dan Keuangan, 1(Agustus), 60-74.

Sofiah, N.S dan Rully Trihantana. (2016). Pengaruh Nisbah Bagi Hasil Deposito Mudharabah Terhadap Loyalitas Nasabah. Jurnal Syarikah, Vol 2 (2).

Sugiyono. (2013). Metode Penelitian Kuantitaif, Kualitatif dan R E D. Bandung: Alfabeta.

Yona, Rika Delfa. (2014). Penyelesaian Sengketa Perbankan Syariah Indonesia. Jurnal Ekonomi dan Hukum Islam, Vol 4 (1).

Yose, Mardiana \& Rully Trihantana. (2017). Peran Serta dan Mekanisme Bank Syariah pada Pembiayaan Sindikasi di Bank Syariah Mandiri Pusat. Jurnal Nisbah, Vol. 3(2). 